\title{
Constructing the autobiographical self, collective identity and spiritual spaces in South African queer autobiography
}

\begin{tabular}{|c|c|}
\hline \multicolumn{2}{|c|}{$\begin{array}{l}\text { Authors: } \\
\text { Barrington M. Marais } \\
\text { Cheryl Stobie }^{1}\end{array}$} \\
\hline \multicolumn{2}{|c|}{$\begin{array}{l}\text { Affiliations: } \\
{ }^{1} \text { English Studies, University } \\
\text { of KwaZulu-Natal, } \\
\text { Pietermaritzburg Campus, } \\
\text { South Africa }\end{array}$} \\
\hline \multicolumn{2}{|c|}{$\begin{array}{l}\text { Correspondence to: } \\
\text { Barrington Marais }\end{array}$} \\
\hline \multicolumn{2}{|c|}{$\begin{array}{l}\text { Email: } \\
\text { barrington.marais@gmail. } \\
\text { com }\end{array}$} \\
\hline \multicolumn{2}{|c|}{$\begin{array}{l}\text { Postal address: } \\
\text { Office B1, Commerce } \\
\text { Basement, University of } \\
\text { KwaZulu-Natal, King Edward } \\
\text { Avenue, Pietermaritzburg } \\
\text { 3201, South Africa }\end{array}$} \\
\hline $\begin{array}{l}\text { Dates: } \\
\text { Received: } 21 \mathrm{~A} \\
\text { Accepted: } 16 \mathrm{~J} \\
\text { Published: } 31 \mathrm{~J}\end{array}$ & $\begin{array}{l}\text { Jug. } 2013 \\
\text { Ian. } 2014 \\
\text { July } 2014\end{array}$ \\
\hline \multicolumn{2}{|c|}{$\begin{array}{l}\text { How to cite this article: } \\
\text { Marais, B.M. \& Stobie, } \\
\text { C., 2014, 'Constructing } \\
\text { the autobiographical } \\
\text { self, collective identity } \\
\text { and spiritual spaces in } \\
\text { South African queer } \\
\text { autobiography', Literator } \\
\text { 35(1), Art. \#1081, } 9 \text { pages. } \\
\text { http://dx.doi.org/10.4102/lit. } \\
\text { v35i1.1081 }\end{array}$} \\
\hline \multicolumn{2}{|c|}{$\begin{array}{l}\text { Note: } \\
\text { The article arises from } \\
\text { research supervised by } \\
\text { Professor Cheryl Stobie } \\
\text { as part of Barrington } \\
\text { Marais's MA degree on the } \\
\text { Pietermaritzburg Campus of } \\
\text { the University of KwaZulu- } \\
\text { Natal, South Africa. }\end{array}$} \\
\hline $\begin{array}{l}\text { Copyright: } \\
\text { (c) 2014. The A } \\
\text { Licensee: AOSI } \\
\text { OpenJournals. } \\
\text { is licensed und } \\
\text { Creative Comm } \\
\text { Attribution Lice }\end{array}$ & $\begin{array}{l}\text { uthors. } \\
\text { IS } \\
\text { This work } \\
\text { ler the } \\
\text { nons } \\
\text { ense. }\end{array}$ \\
\hline Read online: & $\begin{array}{l}\text { Scan this QR } \\
\text { code with your } \\
\text { smart phone or } \\
\text { mobile device } \\
\text { to read online. }\end{array}$ \\
\hline
\end{tabular}

This article examines four recent collections of South African queer autobiographies. These are: Hijab: Unveiling queer Muslim lives, Yes I am! Writing by South African gay men, Reclaiming the L-word: Sappho's daughters out in Africa and Trans: Transgender life stories from South Africa. Selected narratives from each collection have been analysed in order to exhibit the relational nature of autobiographical self-construction through an exploration of how it is specifically constructed in spiritual or religious spaces. The ubuntu theology of Archbishop Emeritus Desmond Tutu is analysed as it intersects with representations of spirituality and religion in the texts. This article seeks to highlight the socio-political value of the texts and their functioning as important tools in the struggle for equality in which the queer minority currently find themselves.

Die konstruering van die outobiografiese self, kollektiewe identiteit en spirituele ruimtes in Suid-Afrikaanse 'queer' outobiografie. Hierdie artikel ondersoek vier onlangse versamelings van Suid-Afrikaanse 'queer' outobiografieë: Hijab: Unveiling queer Muslim lives, Yes I am! Writing by South African gay men, Reclaiming the L-word: Sappho's daughters out in Africa en Trans: Transgender life stories from South Africa. Geselekteerde vertellings uit elke versameling is ontleed om die relasionele aard van outobiografiese selfkonstruksie aan te toon deur middel van 'n ondersoek na hoe dit spesifiek in spirituele of religieuse ruimtes gekonstrueer word. Die $u b u n t u$-teologie van Aartsbiskop Emeritus Desmond Tutu is geanaliseer aangesien dit met die voorstellings van spiritualiteit en religie in die tekste verband hou. Hierdie artikel poog om die sosio-politieke waarde van die tekste uit te lig asook hul funksie as belangrike instrumente in die stryd vir gelykheid waarin die 'queer' minderheid hulleself tans bevind.

\section{Introduction}

The rights of the lesbian, gay, bisexual and transgender (LGBT) community are currently at the forefront of debate across South African cultural and political landscapes. This fact and the number of highly publicised hate crimes against individuals within the LGBT community in South Africa presented the starting point for this article. In 2006, the current state president, Jacob Zuma, whilst speaking at a political rally, was reported to have stated, 'When I was growing up, an ungqingili [homosexual individual] would not have stood in front of me. I would knock him

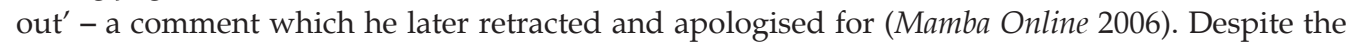
existence of similar attitudes towards the LGBT community at various levels of South African society, in line with its non-discrimination clause, the Constitution makes provision for the protection of the rights of transgender individuals and sexual minorities who may or may not fall within the identity categories of the LGBT acronym.

The Civil Union Act (Republic of South Africa 2006) allows that individuals of the same sex may enter into legally recognised civil partnerships, and this piece of legislation places South Africa far ahead of a number of countries in terms of gender- and sexuality-based rights. Most notably, South Africa is the only African country that recognises civil unions between partners of the same sex. Recently, various news sources, including Mamba Online (2012a), have reported that the House of Traditional Leaders of South Africa has called for the removal from the Constitution's Bill of Rights, chapter 2, section 9 (Republic of South Africa 1996) of the provision for the protection of rights based on sexuality. This issue represents just one facet of the numerous debates surrounding gender and sexuality that are taking place within South African society at present.

Recently, there has been a slew of highly publicised hate crimes against LGBT individuals in South Africa. It has been documented that lesbians in many townships live in fear of 'corrective 
rape'. This form of hate crime sees the perpetrators physically and verbally attack lesbians in the belief that they can 'cure' the victim of the 'illness' of homosexuality through sexual acts with males and thus, inevitably, through the act of rape. The Mail E Guardian reported on the case of Duduzile Zozo (in Thokoza, Gauteng) who was brutally attacked and murdered earlier this year with a toilet brush found lodged in her vagina (Nandipha 2013). Her murder is believed to be linked to one of many corrective rapes which have taken place in South Africa over the years.

Also fresh in the memory of many South Africans is the brutal murder of Kuruman (in the Northern Cape) resident, Thapelo Makutle, a 23-year-old self-identified transgender and gay man. Mamba Online (2012b) reported that Makutle was brutally mutilated and killed after an argument about his sexuality and gender had taken place at a local tavern. Speculation still exists around whether or not his murder was a hate crime. However, for the LGBT community of Kuruman, there is no doubt that Makutle was killed due to a high intolerance for LGBT individuals within their community.

The four collections that will be examined in this article are Hijab: Unveiling queer Muslim lives (Hendricks 2009), Yes I am! Writing by South African gay men (Malan \& Johaardien 2010), Reclaiming the L-word: Sappho's daughters out in Africa (Diesel 2011) and Trans: Transgender life stories from South Africa (Morgan, Marais \& Wellbeloved 2011). These texts provide a range of first-person accounts of the lives of LGBT people in present-day South Africa.

An initial point of concern that requires consideration is the decision to use the term 'queer autobiography' in this article, and in order to do so, the term must be unpacked so that 'queer' and 'autobiography' can be understood as they stand individually. Historically, queer was viewed as a derogatory term used negatively in describing individuals who belonged to sexual minorities. However, as time went on, the term was 'reclaimed', and its usage became more positive. During the late 1980s and the early 1990s, queer theory began to emerge with the works of authors such as Sedgwick (1990), Butler (1990) and Warner (1993). Queer theory is concerned with issues surrounding identity, gender and sexuality. It challenges and problematizes normativity in terms of gender and sexuality and the boundaries it creates. At the same time, it also attempts to avoid the creation of new boundaries and restrictions that may arise from the LGBT category. For example, Butler (1990:3) suggests that 'gay and lesbian' signify somewhat redundant and problematic identity categories, categories which have collectively and incorrectly been assigned a common identity. Furthermore, these categories also ignore important overlapping and varied differences in the areas of class, race and ethnicity (ibid:3).

The term 'autobiography' is undeniably complex, and it may be argued that it cannot be directly applied to the individual accounts which have been isolated from the four collections named above. Nonetheless, these accounts have been referred to as autobiographies based on the following definition provided by prominent life-writing scholars, Smith and Watson (2001):

[Life writing] is an overarching term used for a variety of nonfictional modes of writing that claim to engage with the shaping of someone's life. The writing of one's own life is autobiographical, the writing of another's is biographical; but that boundary is sometimes permeable. (p. 197)

Strictly speaking, each of the accounts examined, however short, is autobiographical because they are essentially literarily documented, first person, written accounts of a life lived.

Furthermore, terming a piece of life writing a 'queer autobiography' is inherently problematic as it deems the queer facet of an individual's identity as the most defining, and considering the complex nature of both 'queer' and 'autobiography' as terms, it is certainly not easy to decide what 'queer autobiography' is. Any attempt to simplify or prescribe a definition for 'queer autobiography' would be near impossible. The four collections of short autobiographical accounts under scrutiny almost all explicitly identify the writers whose stories are contained in the respective collections in terms of the LGBT categories. Thus, the queer facet of identity becomes the vantage point from which the experiences of living are documented. In labelling these collections 'queer autobiography', this article does not favour the respective authors' queerness or imply that it be considered the most defining trait of their character.

These collections have been chosen mainly because they collectively represent a notable trend in the area of life writing and its intersection with LGBT issues in the South African context. Each of the primary texts is fairly new: all emerging at an interesting time in South Africa's history. The country has very recently reached critical milestones in terms of the legal rights of LGBT individuals, especially when one considers the advances in terms of legislation such as the Civil Union Act (Republic of South Africa 2006) and The Implementation of The Alteration of Sex Description and Sex Status Act (Republic of South Africa 2003). The oldest of the four texts were both initially published in 2009 (Trans: Transgender life stories from South Africa and Hijab: Unveiling queer Muslim lives) and the two most recent were published consecutively in 2010 and 2011 (Yes I am! Writing by South African gay men and Reclaiming the L-word: Sappho's daughters out in Africa respectively). Thus, the stories contained within each anthology are reflective of current attitudes and discourses regarding the lives of LGBT individuals and related issues. A number of chosen narratives from each collection have been selected in order to engage in a critical exploration of the construction of autobiographical selfhood through the theoretical lens of collective identity and the African humanist concept of ubuntu. The relational nature of autobiographical self-construction is illustrated through an examination of how it is specifically constructed in spiritual or religious spaces. The ubuntu theology of Archbishop Emeritus Tutu is also analysed as it intersects 
with spirituality and religion. Ubuntu theology offers new, progressive ways of positioning the queer autobiographical self in terms of spiritual or religious inclinations, especially when one considers the often discriminatory manner in which monotheistic religions view the position of queer-identifying individuals. Significantly, Tutu was recently quoted as saying, 'I would refuse to go to a homophobic heaven. No, I would say sorry, I mean I would much rather go to the other place' at the launch of the Free and Equal campaign in Cape Town (British Broadcasting Corporation [BBC] 2013). This article seeks to engage with the socio-political value inherent in the primary texts and how they function as vital tools in the struggle for equality in which the queer minority is currently engaged.

The discussion moves through three phases, beginning with an exploration of the points at which spirituality and religion intersect with queer identity. Further on, there is an examination of the $u b u n t u$ theology of Archbishop Emeritus Desmond Tutu and how it functions. Lastly, the various narratives that have been chosen from each of the collections of autobiographies are analysed in light of collective identity and ubuntu theology.

\section{Religion and spirituality in the collections}

Through engagement with the autobiographical accounts in each of the chosen texts, it becomes evident that representations of Christianity, Islam and Traditional African Spirituality are the dominant systems of belief represented in each of the collections of short autobiographies. Religion is usually represented as an othering force by the queer individuals in the texts. They are constantly embattled, trying to reconcile their queer identity with the expectations and regulations of their various religious orders. Religion is also often presented as a hierarchical, patriarchal, heteronormative and gender-normative institution. The autobiographical subjects in the texts often acknowledge within themselves a deep desire for a connection and relationship with God, but religion as an institution often excludes them on the basis of their queer identity. This is not to say that religion is represented as an entirely alienating force in the primary texts as some individuals relate how they have been able to find acceptance and to forge nurturing relationships in spiritual contexts. Religious spaces are represented as important meeting grounds where people forge personal and collective identities. Institutions such as the Christian church, for example, premise many of their beliefs on interconnectedness through religious kinship and communal practices.

Marsh (2012:261) presents an idea of religion as 'referring to a sociological phenomenon, entailing inclusion/exclusion from socially and politically valorized faith communities that produce and support ... "plausibility structures" that anchor the sense of belonging in community'. Religion is portrayed as legalistic, staunch and specific in terms of what it deems to be right and wrong. In this manner, queer identity often presents something problematic for religion and its expectations in terms of gender and sexuality. In the 2007 documentary film Jihad for love (Sharma 2007), queer identity is placed in direct contrast with practices of Islam. The filmmaker visits numerous countries around the world - including South Africa, Egypt and Morocco - documenting some of the struggles faced by queer Muslims. This film presented the departure point for the specific focus on religion and spirituality in this article.

In the South African context, it may be argued that it is difficult to separate queer identity and religion because the two consistently intersect at various levels. According to the 2001 Census, roughly $83 \%$ of South Africans identify themselves as religious or spiritual. The 2011 Census did not address issues relating to spirituality and religion due to other high-priority concerns (Statistics South Africa n.d. $)^{1}$. In order to give a general idea of how spirituality features in each of the primary texts, a numerical overview of the representation of spirituality or religion is useful. In Reclaiming the L-word: Sappho's daughters out in Africa, religion or spirituality appears in 10 of the 15 short autobiographical accounts that are featured in the collection. Yes I am! Writing by South African gay men contains 36 autobiographical accounts, and issues relating to spirituality or religion appear in 13 of these. In Trans: Transgender life stories from South Africa, issues of spirituality or religion appear in 13 of the 28 autobiographical accounts featured in the collection. Notably, it includes a group discussion that was held with all the individuals whose stories are featured in the collection, except two who could not attend. One of the issues discussed in this group session was the issue of spirituality or religion. Religion or spirituality appears to be a substantial concern of these individuals, and Charl, a participant in the discussion, notes that grappling with issues relating to his gender identity has resulted in an increased understanding of his religious or spiritual practices (Morgan et al. 2011:227). Regarding Reclaiming the L-word: Sappho's daughters out in Africa, Murray (2012:91) correctly highlights the fact that 'a number of chapters ... refer to how sexuality and religion intersect'. Furthermore, she foregrounds the fact that religion or spirituality is an important area of concern amongst gay and lesbian South Africans, drawing attention to a twovolume collection entitled Aliens in the household of God and Christian faith in South Africa (Germond \& De Gruchy 1997). This collection features what are referred to as 'testimonies' of individuals who identify as spiritual or religious and queer.

\section{Ubuntu and ubuntu theology}

Louw (1998) suggests that, unlike Western forms of humanism, African humanism is often connected to issues of spirituality:

While western humanism tends to underestimate or even deny the importance of religious beliefs, ubuntu or African humanism is resiliently religious. For the westerner, the maxim 'a person is a person through other persons' has no obvious religious

1.It must be noted that the 2001 Census is used a point of reference because of this fact. 
connotations ... However, in African tradition this maxim has deeply religious meaning. The person one is to become 'through other persons' is, ultimately, an ancestor. And by the same token, these 'other persons' include ancestors. Ancestors are extended family. Dying is the ultimate homecoming. Not only the living must share and care for each other, but the living and dead depend on each other. (n.p.)

Thus, ubuntu functions as a spiritual as well as a humanist concept. Traditional African spiritualities place a substantial focus on the living existing in harmony with the ancestors as well as with fellow human beings. In fact, as will be discussed later, certain autobiographical accounts describe the experiences of individuals who attribute the queer facets of their identity to connections with particular ancestors. Louw (1998:n.p.) further suggests that 'ubuntu inevitably implies a deep respect and regard for religious beliefs and practices'. The concept of interconnectedness on which ubuntu is based also extends to the spiritual realm with the ancestors.

Traditional forms of African Spirituality and monotheistic religion often exist in contention with each other. Traditional African Spiritualities hold in high regard the role and place of the ancestors in the lives of the living whereas Christianity, for example, views such beliefs relating to ancestral worship as problematic. The expectation in Christianity is that only the supreme God is venerated and worshipped. Similarly, traditional African belief systems, and their consideration of ancestor veneration as vitally important, may problematise the place of individuals who choose not to acknowledge their ancestors in worship. Even though these differences exist, many Africans live in a manner that balances their traditional African beliefs with Christianity, highlighting the possibility for a meeting ground between African Spirituality and Christianity.

In many ways, ubuntu serves as this meeting ground as it 'underscores the importance of agreement', and this agreement is only achieved through lengthy dialogue that considers the importance of each individual's belief systems, and also that of the extended community (Louw 1998:n.p.). The consideration of the importance of the extended community does not presuppose oppressive 'sameness', but rather, it acknowledges the necessity of functioning successfully on a personal level and also on a communal level. This understanding of ubuntu as a spiritual as well as humanist concept provides a platform from which to investigate the ubuntu theology of Archbishop Emeritus Desmond Tutu.

Over the years, Tutu has acknowledged the need for uniquely African forms of Christianity. In the introduction to An African prayer book, Tutu (1995) retells the biblical story of creation, relating how God, after creating Adam, and watching him enjoy the wonders of Eden, realised the need to create a companion for him:

This beautiful story tells a fundamental truth about us - that we are made to live in a delicate network of interdependence with one another, with God and with the rest of creation. We say in our African idiom: 'A person is a person through other persons'. A solitary human being is a contradiction in terms. (p. xiv)

This forms the basis for understanding Tutu's ubuntu theology. It arises from the simple idea that human life is ultimately interconnected through oneness with God: 'After all, we are created in the image of a God who is a diversity of persons who exist in ineffable unity' (Tutu 1995:xiv-xv).

\section{With regard to Tutu's ubuntu theology, Battle (1997) notes:}

Tutu tirelessly denied that the color of one's skin can be an index of one's value as a human being. Indeed his Ubuntu Theology can be understood in its entirety as a Christian rebuttal to such a claim. (p. 1)

This view of Tutu's ubuntu theology posits its functioning as a Christian tool against one form of discrimination, namely racism or racial discrimination. Battle's suggestion that it should be understood to function in this particular manner in its absolute entirety is flawed, as it reduces the general applicability of Tutu's ubuntu theology to issues beyond racism. Although much of Tutu's life has been concerned with aiding the fight for a democratic South Africa that is free from apartheid's evils, Tutu's awareness of the issues relating to human rights in general is exceptional. Tutu has been an active figure in human rights battles in all forms, not just racism and the politics of racism. He has been continuously and boldly vocal with regard to numerous human rights issues, including xenophobia and homophobia. During a 2004 sermon, Tutu said:

A student once asked me if I could have one wish granted to reverse an injustice, what would it be? I had to ask for two. One is for world leaders to forgive the debts of developing nations which hold them in such thrall. The other is for the world to end the persecution of people because of their sexual orientation, which is every bit as unjust as that crime against humanity, apartheid. (Huffington Post 2011)

Thus, although racial discrimination may have been the starting point in realising an ubuntu form of Christian theology, it cannot be considered as limited to this issue. Tutu's ubuntu theology may be considered a 'Christian rebuttal' to discrimination in all its varied forms (Battle 1997:1).

Battle (1997:64) emphasises the fact that ubuntu theology acknowledges the interconnectedness of human life through the individual's connection with a supreme God, thus humanity becomes connected through oneness with God. Therefore, in religious and spiritual spaces where Western models of identity may neglect the relative importance of the relationality of experience, an ubuntuist perspective is a reminder that there is a shared identity in all individuals, despite the fact that human beings exist separately in many ways. Battle (1997) quotes Tutu's statement:

God says, it is precisely our diversity that makes for our unity. It is precisely because you are you and I am me that [God] says, 'you hold on together'. (p. 64) 
Thus, God becomes the area of common ground, and human beings can move away from discriminatory models of religion. This shift can be achieved through venturing beyond the singularity of each person and what one would deem the shortcomings of another and through moving towards the God that sustains them all. Ubuntu theology succeeds in that it works to break down hierarchies and binaries. For example, Tutu's involvement in the Truth and Reconciliation Commission was based on a model of justice and forgiveness. Battle (1997) illustrates how Tutu's ubuntu theology is a:

... theological model ... [that] seeks to restore the oppressor's humanity by releasing and enabling the oppressed as peers under God. The relationship of oppressed and oppressor and the resulting definition of humanity through racial classification are broken through ubuntu, an alternative way of being in a hostile world. (p. 5)

The example of oppressed and oppressor in terms of racial identification used above can be applied to discrimination and the forms it takes across various identity categories. Ubuntu theology does not privilege those who share in a common faith as do communal practices in many religions. Instead, it focuses on the shared nature of the human experience, not just the Christian or Muslim experience, for example. As the main priority of this article is literary analysis, this concise overview of the manner in which Tutu's ubuntu theology functions and the ideals on which it is based will have to suffice. In addition, rather than aiming to present a predominantly Christian view of religion, the intention is to illustrate how $u b u n t u$ is effective in calling into question discriminatory practices within religion, regardless of the form these practices might take.

Attaching $u b u n t u$ ideals to the functioning of religion serves as a reminder that human beings exist in diversity. This diversity, however, should not be the cause of isolation and condemnation as there always exists the intrinsic and shared experience of being human. Just as apartheid notions of religion favoured the white majority and had to be called into question, so too do patriarchal, heteronormative and gender-normative notions of religion need questioning. An ubuntuist approach to religion may provide the starting point for such discourses. Exploring the manner in which religion is represented in the primary texts will illuminate the intersections it forms with queer identity and ubuntu.

\section{The self, collective identity and spiritual spaces}

The interaction in spiritual or religious spaces is not only with God. In whichever form worship may take place, the spiritual experience is embedded in collective identities through religion and religious practices. Thus the manner in which the autobiographical self as spiritual is constructed in the texts under examination is inherently relational. It is influenced by spiritual leaders as well as peers. Staude (2005:257) highlights the fact that autobiography and issues of spirituality have consistently intersected over time, citing the stories of Abraham, Moses, Joseph and Solomon in the Hebrew Bible as examples of attempts by human beings to begin grappling with issues of the soul. Spirituality is a concern that is raised numerous times in the texts under scrutiny, and although it is seldom presented in line with the traditional spiritual autobiographical form, it is portrayed as an important part of the autobiographical subjects' sense of self. Staude (ibid:258) highlights the fact that classic spiritual autobiography concerns itself with issues of confession or conversion in terms of narrative concerns and structure. Although these elements do feature in the primary texts, they are not necessarily dominant concerns. Thus the intention is not to discuss and analyse each autobiographical account as a spiritual autobiography but rather to investigate the overall place of spirituality in the narrative. It will be argued that the collective identities forged under spirituality and religion contribute to the manner in which queer autobiographical selfhood is constructed.

Marsh (2012:263) positions autobiographical accounts by queer individuals as providing 'multiple sites of resistance to dominant prevailing myths' as these accounts call into question the heteronormative and gender-normative models that religion often favours. Bringing together discourses relating to queer and religion problematises prevailing views of queer identity. The intention is not to examine the texts solely in terms of the manner in which they politicise queer identity. However, the act of placing queer identity in contrast with a dominant social concern such as religion makes the autobiographical act in these cases inherently political. An appropriate place to situate an analysis of the texts is in relation to the autobiographies of leaders in various religious orders.

Hendricks, whose short autobiographical account features in Yes I am! Writing by South African gay men, has dedicated his life to positioning the queer minority within the Islamic faith. As the founder and director of The Inner Circle - a Cape Town based organisation concerned with queer Muslim issues, also responsible for the publication of Hijab: Unveiling queer Muslim lives - his battle is not solely a personal one as he has assumed a leadership role within the queer Muslim community through his extensive work. In the foreword to Hijab: Unveiling queer Muslim lives, Hendricks (2009) notes:

I have always felt a deep sense of obligation to the struggle of Queer Muslims. Is it a good Muslim practice to disregard someone who is different from the mainstream simply because they are not fitting in with our interpretation of Islam? (p. vii)

The sense of obligation he feels towards the struggle of queer Muslims presents the position of the queer religious leader in an interesting light. Kugle (2010:3) notes that queer identity is often a complex issue within the realms of Islam with many scholars citing verses from the Holy Quran as either justification or condemnation for queer identity. However, what is evident from the case of Hendricks is that, when religious leaders speak out on their own queer identity, the barriers of religious prohibitions are actively broken down. 
In a short reflection entitled 'Gay in the image of God', featured in Yes I am! Writing by South African gay men, Gaum (2010) shares his thoughts just before his ordination as a pastor was revoked by a church committee because he had been involved in a relationship with another man. Although abstract and short, this reflection by Gaum provides insight into the manner in which the author is able to create an understanding of the queer self and the spiritual. In his reflection, Gaum uses the images of God's creation of human beings in Genesis in an attempt to rationalise his queer identity. He considers his own version of the Bible verses in Genesis 1 verses 27 and 31:

On the sixth day God created humans to be like God's self, God made men and women. God looked at what God had done. All of it was very good!

Gaum 2010 then presents the following thought process:

I am created in the image of God.

I am created gay in the image of God.

God created me gay - looking like God.

Perhaps God created you straight - looking like God.

God created you a man - in his image.

God created you a woman - in her image.

We are all people who look like God - irrespective of our differences. (p. 94)

The above highlights Gaum's (2010) attempt to reason the origins of his identification as queer. He acknowledges the fact that the Bible narrates that all individuals are made in the image of God, and in this manner, he deduces that members of humanity, as God's creation, are brought together through their oneness with God. Gaum actively acknowledges that his sense of selfhood as a Christian is linked only to his identification with God. The ideas on which he reflected in this short account are similar to Tutu's ubuntu theology and its focus on a relationship with God as opposed to a focus on the various differences in the human experience. Gaum's reflections in this piece indicate a deep ubuntu awareness, whether conscious or not.

Furthermore, Gaum's (2010:94) representation of his queer identity as arising from God is compelling in that it does not separate the queer facet of his identity from his identification with God: 'God created me gay - looking like God'. The self as gay does not become separated from the self as identifying with being created in the image of God. Instead of questioning himself and condemning his sexuality, Gaum instead questions the belief systems of dominant religious orders as well as society's reaction to the fact that he is gay. The self, for Gaum, is seen and represented as being deeply in touch with God and reflecting God's purpose even through queer identity. Gaum's identification with the queer aspects of his selfhood as being created in him by God represents a bold statement in that he actively acknowledges that queer identity and religious identity are not separate.

Often many individuals in the primary texts chastise themselves with regard to the queer facets of their identity, and thus, the position of religious leaders like Gaum becomes important in assisting the walk of ordinary followers of the different religions. For these 'ordinary followers', the fact that they may identify as queer is often seen and represented as ungodly and an abomination. For instance, in the anonymous account 'A road less travelled', which features in Hijab: Unveiling queer Muslim lives, the narrator recounts:

I had started relating to my homosexuality and religion as an affliction that I would not be able to shake off. For God's sake, I was a born-again Christian and homosexual! What would my mother say?! I believed that I was surely going to hell. Since I could not marry these two aspects of myself, let alone exist within a duality of this nature, I chose to forego and disavow the God of my mother. I was alone. (Hendricks 2009:55)

The narrator acknowledges the fact that he views his religious identity and sexual identity as not being able to coexist, mainly because his identification as a gay man was something morally reprehensible in the light of religious expectations. The above quotation presents a poignant picture of the struggles of the autobiographical subject to find worth as an individual who desired a relationship with God but who was also queer. His experiences relating to religion position his sexual nature and identity as sinful and ultimately problematic. For the narrator, the only option for him is to denounce religion in attempts to grapple with issues of his sexuality and establish some sense of belonging. The autobiographical subject thus exists in a state of alienation from God, and Marsh (2012:262263) suggests that, 'alienated from the dominant cultural and political models, the queer self - destabilized by its bruising encounters with homophobic "cultures of insult" - may be forced into ontological doubt'. Thus, in journeying away from the site that problematises and condemns his queer identity, the autobiographical self as queer begins an attempt to locate meaning and acceptance in other places away from the condemnation of religion.

O'Brien (2004:184) significantly highlights the fact that the 'rejection discourses' of Christianity relating to queer identity often result in non-Christians assuming 'that the simplest path would be the renunciation of religion'. This idea does not solely apply to Christianity and may be extended to religion in general. For example, in a short account featured in Reclaiming the L-word: Sappho's daughters out in Africa, Maharaj (2011:66), who was brought up Hindu, points out the fact that 'religion limits and constrains' the individual, and thus she has chosen to forego identifying with religion. However, this is not entirely the easiest route for many individuals in the LGBT community as many experience the need to exist simultaneously as both religious or spiritual and queer. O'Brien's observation presented above may be extended to individuals across different religions as similar themes arise within the primary texts across varied representations of religion.

\section{African spirituality}

Although monotheistic concepts of a supreme 'God' as portrayed in the primary texts have dominated the analysis up to this point, various accounts explore the relationship 
between African spirituality and queer identity. As noted in the discussion of ubuntu theology earlier in this article, African spirituality greatly values the role of ancestral spirits and the interactions that the living have with them. In the autobiographical account entitled 'Tebogo's story: My ancestor was living through me' (Tebogo 2011:119), featured in Trans: Transgender life stories from South Africa, Tebogo, who identifies as a 'female to male [FTM] transsexual', briefly chronicles his journey in overcoming issues related to his transgender identity. Tebogo recounts his journey in coming to understand his transgender identity, recalling how he initially identified as lesbian until he was able to understand and grapple with his transgender identity. Tebogo (2011:121) notes that at the age of 12 he began to suffer from an illness that was later diagnosed as a calling from his great-grandfather to become a traditional healer (sangoma). Tebogo (2011) foregrounds his identification as a Christian at a particular point in his life, and his assumption that different religious affiliations are mutually exclusive:

Before the calling I was a Christian who used to pray and preach to other pupils during break time. At the time, I believed that it wasn't possible to be a Christian and a sangoma at the same time. (p. 121)

Tebogo later comes to realise that he has a desire to be Christian despite his vocation as a traditional healer, and he attempts to reconcile the two. What is most notable about Tebogo's (2011) spiritual journey is the fact that his transgender identity has been attributed to the presence of the ancestral spirit of his great-grandfather in his life:

My parents accepted me, because they could tell that perhaps my ancestors were making me play the role I played. My ancestor was living through me because he is male. They weren't aware of my relations with females. They didn't think I'd reached that stage, but they accepted my lifestyle. 'It's his ancestors, let's just accept it', they'd say. (p. 121)

Tebogo (2011:121) notes how this line of thinking, relating to his transgender identity, was perpetuated by his family, friends and his community, resulting in his also adopting the opinion that his queer identity was a direct result of his spiritual connection to his ancestors.

In chapter seven of the book Tommy boys, lesbian men and ancestral wives (Morgan \& Wieringa 2005), Nkabinde and Morgan (2005) relate a number of thought-provoking interviews with lesbian and transgender sangomas regarding same-sex practices and homosexual identity. Nkabinde's own autobiography, Black bull, ancestors and me: My life as a lesbian sangoma, appeared in 2008. In her autobiography, Nkabinde (2008) maintains the belief that for many sangomas their sexual or gender identity is often a direct result of their spiritual connection with a specific ancestor or ancestors. This view is also held by many of the interviewees in Tommy boys, lesbian men and ancestral wives. One of the interviewees, Hlengiwe, who is in a same-sex relationship with a woman named Nomsa, states the following with regard to their relationship: 'Muzi chose her; I didn't have anything to do with it' (Nkabinde \& Morgan, in Morgan \& Wieringa
2005:242). Muzi, Hlengiwe's dominant ancestor, is male. Nkabinde (2005) explains Hlengiwe's statement, noting the following:

The dominant male ancestor, who is often unmarried at the time of his death, usually chooses a wife whom he instructs his female sangoma to marry. Hlengiwe feels that Nomsa was chosen for her by her ancestor and that she had no choice in the matter. (p. 242)

The above example of Hlengiwe and Nomsa's relationship presents a pertinent dynamic in terms of spiritual identity and sexuality in that Hlengiwe's spiritual identity with her ancestor intertwines with her physical existence to the extent that it shapes her sexual relationships. Thus, the relational nature of her spiritual identity with her male ancestor, Muzi, is what determines the nature of her romantic and sexual relationships. In these circumstances, the traditional categories of gender and sexual identity as prescribed by Western discourses become blurred as Hlengiwe cannot be specifically categorised in terms of her gender or sexuality, and neither does she desire to be.

In Tebogo's (2011:120) case, he reveals an understanding of terms such as 'lesbian' and 'transgender'. These terms are commonly used and encountered in the urbanised setting of his community and have been helpful in assisting him in grappling with issues of identity. His first encounter with a term denoting queer identity was with the slang word 'transie' - which he believed was used to describe an intersex person, and he learnt the word 'lesbian' in 'standard 5 or 6 '. For Tebogo, his spirituality, as represented in the text, is positioned as being vital to understanding his queer identifications, and it acts as a reference point in constructing the identity of the autobiographical self. This particular account presents a variant understanding of the relationality inherent in identity construction, in that it positions identity as existing across the spiritual and natural realms, that is, from his ancestor in the spirit world directly to him in the natural world. Although Tebogo has acquired terms to label his queer identity, terms that might be foreign to someone like Hlengiwe, for example, the nature of his queer identity is not only rooted in his spiritual beliefs and convictions but also his understandings of his personal identity. With regard to Nkabinde's autobiography, it has been observed by Stobie (2011) that:

[ $t$ ]he condemnation of female embodiment and possession by a male spirit is also problematic, as it brings to the fore a conflict between Nkabinde's reverence for tradition and her feminist, urban, modernist beliefs in the provisions of the South African Constitution. (pp. 150-151)

Similarly for Tebogo (2011), the awareness of Western models of gender and sexuality categorisation provide him with a mode to identify himself, and this is at odds with his spiritual beliefs, which claim the queer facets of his identity as not being entirely his own but those of his ancestor which have manifested through him. The complex nature of representations of religion, sexuality and gender in Nkabinde's autobiography has been noted by Stobie (2011): 
The book thus offers a view of sexual energy working in tandem with spiritual power, a worldview diametrically opposed to the value system of Christianity, which often advocates sexual repression and sublimation; however, it simultaneously reinforces the stereotype of associating sexuality with masculinity. (p. 159)

In a similar manner to Nkabinde's autobiography, both Tebogo's and Hlengiwe's stories actively problematize a number of mainstream religious discourses regarding sex and sexuality which aim to separate the spiritual from the sexual in that they position their sexual and gender identities as being divinely conferred and experienced. However, what also occurs is the reinforcing of stereotypes which strip feminine identity of the ability to act autonomously in terms of sexuality (Stobie 2011:159). Tebogo's spiritual identity is also at times at odds with his own decisions and at the expense of his autonomy. As part of a discussion group held by the editors of Trans: Transgender life stories from South Africa, Tebogo draws attention to a number of issues. On the one hand, Tebogo (2011) notes that his African traditional beliefs allow him the opportunity to change whatever is believed to be wrong with the body, claiming:

In my culture it is believed that when something is wrong with the body, you need to correct it. There is nothing wrong with correcting your body. It is just a body which will make you happy. The person is really inside you. (p. 229)

On the other hand, however, when he chooses to begin transitioning, his failure to alert his ancestors to this fact results in his becoming ill shortly before one of his surgeries, he believes (Tebogo 2011:229). The body is obviously an important site of being for Tebogo as he attempts to change the physical body to match his identification as male, but at the same time, he asserts the relative insignificance of the body in spiritual terms. What this primarily exhibits is the complex working of Tebogo's sexual and gender identity in relation to his spiritual identity.

In many ways, one is aware of the conflict it presents for him. Tebogo (2011) acknowledges the following:

This body is something that contains me, it is not me. My ancestors called me through spirit and that is how they will get me if they want me. That is my personal belief. (p. 229)

The contradictions are evident as he attempts to negotiate the importance of his transition against the relatively insignificant manner in which the body is perceived in terms of his spirituality. The body is necessary for Tebogo as he inhabits it in the material world, but he is acutely aware of the fact that his major goal is towards existence in the spiritual realm. Tebogo's story, like the stories of others who have related their experiences in the autobiographical accounts under scrutiny, presents the complexities that are unavoidable in terms of the intersection between queer identity and spiritual or religious identity. What these texts achieve is the creation of awareness of the multi-layered ways in which identity is negotiated, and thereby they actively promote dialogue in the hope of fostering understanding.

\section{Conclusion}

Individuals often find their queer identity called into question or condemned in religious spaces. However, regardless of this fact, the individuals in the above texts often note a deep desire to engage successfully with their identity as religious or spiritual beings. Relationships in spiritual social locations are vital in the process of constructing versions of the queer autobiographical self as individuals in the texts often do not view their relationship with God as being based on condemnation of their queer identity. Instead, it is religious leaders and peers who perpetuate condemnatory and discriminatory stances on queer identity in religious social locations. In her study of homosexuality and Christianity, O'Brien (2004) highlights the fact that:

... within a heteronormative culture, lesbians and gays are (often painfully) aware they are social cast-offs. Within Christianity, active homosexuals are also aware that in addition to their being social cast-offs, their souls have been cast-off as well ... To experience homosexual desires, and certainly to pursue fulfilment of these desires, will result in being cast off from the cosmology through which one makes sense of one's life. (p. 185)

Extending O'Brien's (2004) observations noted above to queer identity and religion or spirituality in general, it can be observed from the primary texts that the autobiographical subjects are consistently embroiled in such tense deliberations of whether their queer identity is morally and religiously acceptable. Religion or spirituality is often the site at which individuals make sense of the overall importance of their existence, and condemning them from these spaces often leaves individuals in a state of deep existential anxiety. Autobiographical writing can be observed as a powerful tool in assisting individuals as they actively work through their fears and concerns, and it also aids them in understanding their position with regard to the dominant cultural belief systems of society.

Marsh (2012) observes the following:

First-person testimony, in the form of memoir or other autobiographical texts, challenges the 'discursive colonization' that would position queer folk at the margins of a full humanity, and reconfigures the myths that sustain the hegemonic control of dominant and homophobic religious ideologies. (p. 263)

Thus, these autobiographical texts assume an inherently politicised rolein that they question and force a reconsideration of the manner in which queer identity is viewed in religious discourses. Each of the short autobiographical accounts discussed here represents the problematic stance of religion on queer issues and the need for changed perceptions regarding the queer minority. Religion itself is often not entirely foregone or abandoned by the autobiographical other. Instead, the individuals and encounters which the autobiographical self experiences in religious spaces need to be spotlighted, examined and analysed. Through this process, the individuals, as they are represented autobiographically in the primary texts, are then able to move towards establishing their own understanding and connection to religion, 
sometimes with the support of forward-thinking religious leaders, peers and organisations, and at other times at the peril of a religious experience that is not entirely relational but rather more personal in nature. Traditional religion is often experienced through collectively drawing individual people together into a collective based on the shared nature of their religious identity, and for this reason, exiting the collective is often a difficult experience for the autobiographical self. This is, however, sometimes a profoundly positive experience as the autobiographical self is able to forge new understandings of God as well as queer identity in relation to this new-found concept of God. The concept of ubuntu becomes useful here, and its basis in ideas of equality and communality brings to religion the active rethinking and reimagining of shared identity and acceptance in religious spaces. Archbishop Emeritus Desmond Tutu's ubuntu theology serves as a lesson to spiritual and religious orders in general because it makes space within religion for those who exist outside the ambit of the hegemonic, gender-normative and heteronormative expectations of religious structures.

\section{Acknowledgements}

The work received financial support from the National Research Foundation.

\section{Competing interests}

The authors declare that they have no financial or personal relationship(s) that may have inappropriately influenced the writing of this article.

\section{Authors' contributions}

Both authors, B.M.M. (University of KwaZulu-Natal) and C.S. (University of KwaZulu-Natal) contributed equally to the writing of this article.

\section{References}

Battle, M., 1997, Reconciliation: The ubuntu theology of Desmond Tutu, The Pilgrim Press, Cleveland.

British Broadcasting Corporation (BBC), 2013, Archbishop Tutu 'would not worship a homophobic God', viewed 21 August 2013, from http://www.bbc.co.uk/news/ world-africa-23464694

Butler, J., 1990, Gender trouble: Feminism and the subversion of identity, Routledge, London.

Diesel, A. (ed.), 2011, Reclaiming the L-word: Sappho's daughters out in Africa, Modjaji Books, Athlone.

Gaum, L., 2010, 'Gay in the image of God', in R. Malan \& A. Johaardien (eds.), Yes I am! Writing by South African gay men, pp. 94-95, Junkets Media, Mowbray.

Hendricks, P. (ed.), 2009, Hijab: Unveiling queer Muslim lives, The Inner Circle, Wynburg
Huffington Post, 2011, All are God's children: Including gays and lesbians in the church and society, viewed 09 October 2012, from http://www.huffingtonpost.com/ desmondtutu/religionhomosexuality_b874804.html

Kugle, S.S., 2010, Homosexuality in Islam: Critical reflections on gay, lesbian and transgender Muslims, One World Publications, Oxford.

Louw, D., 1998, 'Ubuntu: An African assessment of the religious other', paper presented at The 20th World Congress of Philosophy, Boston, 10-16th August, viewed 05 May 2012, from http://www.bu.edu/wcp/Papers/Afri/AfriLouw.htm

Mamba Online, 2006, Zuma apologises, viewed 21 July 2012, from http:///www. mambaonline.com/article. asp?artid $=546$

Mamba Online, 2012a, Gay South Africans protest against traditional leaders, viewed 21 July 2012, from http://www.mambaonline.com/article.asp?artid=6964

Mamba Online, 2012b, Kuruman murder: Gruesome details emerge, viewed 21 July 2012, from http://www.mambaonline.com/article.asp?artid-7066

Maharaj, A., 2011, 'My journey', in A. Diesel (ed.), Reclaiming the L-word: Sappho's daughters out in Africa, pp. 61-67, Modjaji Books, Athlone.

Malan, R. \& Johaardien, A. (eds.), 2010, Yes I am! Writing by South African gay men, Junkets Media, Mowbray.

Marsh, V., 2012, 'Writing the spirit: Testimony and the unauthorized voice in queer spiritual memoir', in D.L. Boisvert \& J.E. Johnson (eds.), Queer religion: Homosexuality in modern religious history, vol. 1, Praeger, Santa Barbara.

Morgan, R. \& Wieringa, S. (eds.), 2005, Tommy boys, lesbian men \& ancestral wives, Jacana Media, Johannesburg.

Morgan, R., Marais, C. \& Wellbeloved, J.R. (eds.), 2011, Trans: Transgender life stories from South Africa, Jacana Media, Cape Town.

Murray, J., 2012, 'Is the closet door no more? Critical engagements with lesbianism in the South African context', Scrutiny2: Issues in English Studies in Southern Africa 17(10), 87-99. http://dx.doi.org/10.1080/18125441.2012.706077

Nandipha, K., 2013, “'Corrective rape": Lesbians at the mercy of powerless men', Mail \& Guardian, viewed 03 October 2013, from http://mg.co.za/article/2013-07-1500 -violence-against-black-lesbians-is-a-struggle-for-power

Nkabinde, N.Z. \& Morgan, R., 2005, “'This happened since ancient times ... It's something you are born with": Ancestral wives amongst same-sex sangomas in South Africa', in R. Morgan \& S. Wieringa (eds.), Tommy boys, lesbian men \& ancestral wives, pp. 231-258, Jacana Media, Johannesburg.

Nkabinde, N.Z., 2008, Black bull, ancestors and me: My life as a lesbian sangoma, Fanele, Johannesburg.

O'Brien, J., 2004, 'Wrestling the angel of contradictions: Queer Christian identities', Culture and Religion: An Interdisciplinary Journal 5(2), 179-202. http://dx.doi. org/10.1080/143830042000225420

Republic of South Africa, 1996, Constitution of The Republic South Africa, Bill of Rights: Chapter 2, section 9, viewed 18 March 2014, from http://www.gov.za/documents/ constitution/1996/a108-96.pdf

Republic of South Africa, 2003, Alteration of Sex Description and Sex Status Act, No. 49, viewed 18 March 2014, from http://butterworths.ukzn.ac.za/nxt/gateway. dII?f=templates\$fn=default.htm\$vid=mylnb:10.1048/enu

Republic of South Africa, 2006, Civil Union Act, No. 17, viewed 18 March 2014 from http://butterworths.ukzn.ac.za/nxt/gateway.dll?f=templates $\$ \mathrm{fn}=$ default. $\mathrm{htm} \$$ vid=mylnb:10.1048/enu

Sedgwick, E.K., 1990, Epistemology of the closet, University of California Press, Berkeley.

Sharma, P. (dir.), 2007, Jihad for love, video recording, Logo, United States of America.

Smith, S. \& Watson, J., 2001, Reading autobiography: A guide for interpreting life narratives, University of Minnesota Press, Minneapolis.

Staude, J., 2005, 'Autobiography as a spiritual practice', Journal of Gerontological Social Work 4(3), 246-269.

Statistics South Africa n.d., Census 2011 FAQ, viewed 03 June 2013, from http://www. statssa.gov.za/census2011/faq.asp

Stobie, C., 2011, “'He uses my body”: Female traditional healers, male ancestors and transgender in South Africa', African Identities 9(2), 149-162. http://dx.doi.org/1 $0.1080 / 14725843.2011 .556792$

Tebogo, 2011, 'Tebogo's story: My ancestor was living through me', in R. Morgan, C. Marais \& J.R. Wellbeloved (eds.), Trans: Transgender life stories from South Africa, pp. 119-127, Jacana Media, Cape Town.

Tutu, D., 1995, An African prayer book, Hodder \& Stoughton, London.

Warner, M. (ed.), 1993, Fear of a queer planet: Queer politics and social theory, University of Minnesota Press, Minneapolis. 